\title{
Dietary phenotype and advanced glycation end-products predict WTC-obstructive airways disease: a longitudinal observational study
}

\author{
Rachel Lam¹, Sophia Kwon' ${ }^{1}$, Jessica Riggs ${ }^{1}$, Maria Sunseri ${ }^{1}$, George Crowley ${ }^{1}$, Theresa Schwartz \\ Rachel Zeig-Owens ${ }^{3}$, Hilary Colbeth ${ }^{3}$, Allison Halpren ${ }^{3}$, Mengling Liư ${ }^{2,5}$, David J. Prezant ${ }^{3,4}$ \\ and Anna Nolan ${ }^{1,3,5,6^{*}}$ (D)
}

\begin{abstract}
Background: Diet is a modifier of metabolic syndrome which in turn is associated with World Trade Center obstructive airways disease (WTC-OAD). We have designed this study to (1) assess the dietary phenotype (food types, physical activity, and dietary habits) of the Fire Department of New York (FDNY) WTC-Health Program (WTC-HP) cohort and (2) quantify the association of dietary quality and its advanced glycation end product (AGE) content with the development of WTC-OAD.

Methods: WTC-OAD, defined as developing WTC-Lung Injury (WTC-LI; FEV $1<$ LLN) and/or airway hyperreactivity (AHR; positive methacholine and/or positive bronchodilator response). Rapid Eating and Activity Assessment for Participants-Short Version (REAP-S) deployed on 3/1/2018 in the WTC-HP annual monitoring assessment. Clinical and REAP-S data of consented subjects was extracted (7/17/2019). Diet quality [low-(15-19), moderate-(20-29), and high(30-39)] and AGE content per REAP-S questionnaire were assessed for association with WTC-OAD. Regression models adjusted for smoking, hyperglycemia, hypertension, age on 9/11, WTC-exposure, BMI, and job description.

Results: $N=9508$ completed the annual questionnaire, while $N=4015$ completed REAP-S and had spirometry. WTCOAD developed in $N=921$, while $N=3094$ never developed WTC-OAD. Low- and moderate-dietary quality, eating more (processed meats, fried foods, sugary drinks), fewer (vegetables, whole-grains), and having a diet abundant in AGEs were significantly associated with WTC-OAD. Smoking was not a significant risk factor of WTC-OAD.

Conclusions: REAP-S was successfully implemented in the FDNY WTC-HP monitoring questionnaire and produced valuable dietary phenotyping. Our observational study has identified low dietary quality and AGE abundant dietary habits as risk factors for pulmonary disease in the context of WTC-exposure. Dietary phenotyping, not only focuses our metabolomic/biomarker profiling but also further informs future dietary interventions that may positively impact particulate matter associated lung disease.
\end{abstract}

Keywords: Metabolic syndrome, Nutrition, Diet

\footnotetext{
*Correspondence: anna.nolan@med.nyu.edu

${ }^{6}$ Department of Medicine, Division of Pulmonary, Critical Care and Sleep, New York University, School of Medicine, New Bellevue, 16 S Room 16 (Office), 16N Room 20 (Lab), 462 1st Avenue, New York, NY 10016, USA

Full list of author information is available at the end of the article
}

\section{Background}

Diet and obesity play a role in the development of obstructive airways disease (OAD) [1-3]. Diets focused on reducing inflammation and increasing vegetable and fish consumption reduced the risk of chronic obstructive pulmonary disease (COPD), whereas diets with increased original author(s) and the source, provide a link to the Creative Commons licence, and indicate if changes were made. The images or other third party material in this article are included in the article's Creative Commons licence, unless indicated otherwise in a credit line to the material. If material is not included in the article's Creative Commons licence and your intended use is not permitted by statutory regulation or exceeds the permitted use, you will need to obtain permission directly from the copyright holder. To view a copy of this licence, visit http://creativecommons.org/licenses/by/4.0/. The Creative Commons Public Domain Dedication waiver (http://creativeco mmons.org/publicdomain/zero/1.0/) applies to the data made available in this article, unless otherwise stated in a credit line to the data. 
pro-inflammatory advanced glycation end products (AGE) were associated with disease [4-7]. Low-calorie dietary interventions yielded weight loss and improved lung function in obese asthmatics [8]. The health benefits of weight loss, increased high density lipoprotein (HDL), and decreased triglyceride, have been extensively studied [9-11]. Specifically, Mediterranean diets characterized by high consumption of fruits, vegetables, and fish, were associated with lower COPD, whereas, western diets were significantly associated with higher risk of newly diagnosed COPD [12-16].

Metabolic syndrome (MetSyn) is a risk factor of cardiovascular, lung disease, and World Trade Center-OAD (WTC-OAD) $[15,16]$. MetSyn affects over $30 \%$ of US adults and $23 \%$ of participants in the Fire Department of New York (FDNY) WTC-Health Program (WTC-HP) program [12-19]. Furthermore, metabolic biomarkers, elevated BMI, and a $>2 \mathrm{~kg} / \mathrm{m}^{2}$ BMI increase predicted WTC-OAD [16, 20-23].

Since high-caloric diets are key contributors to MetSyn, nutritional interventions to potentially reverse pulmonary dysfunction have been studied [14-16]. Our in vitro and in vivo models identified that the receptor for AGE (RAGE) is associated with lung dysfunction after WTC-particulate matter (WTC-PM) exposure. Specifically, RAGE deficient WTC-PM exposed mice were protected against WTC-OAD [24-26]. Dietary and endogenous AGEs can impact signaling pathways such as those in inflammatory diseases [27]. Despite evidence that diet and obesity are risks, studies have suggested obesity may have a protective effect on survival and lung function in COPD $[28,29]$. Therefore, to further clarify the effect of diet on lung disease in our WTC-exposed cohort, we studied their dietary patterns.

The Rapid Eating and Activity Assessment for Patients (REAP) and its short version (REAP-S) are advantageous over other independently developed and validated food questionnaires in the primary care setting because of their brevity and ability to quickly evaluate targeted food categories, potential barriers to high dietary quality, and dietary habits [30-43]. REAP-S score has also correlated with other questionnaires investigating OAD [44-48].

To inform our understanding of how diet is a modifier of WTC-OAD, we utilized REAP-S to assess dietary quality and estimate intake of foods such as fat, cholesterol, sugar, and meats and correlated it to disease outcome [30, 43, 47-49]. This study also prospectively evaluated potential barriers to high dietary quality, dietary habits, and food group stratification for AGE content. We hypothesized that WTC-exposed first responders with poor dietary quality and increased AGE content were more likely to have WTC-OAD at any timepoint after 9/11/2001 (9/11).

\section{Methods}

\section{Study design}

This observational study targeted $\mathrm{N}=14,976$ WTC-HP enrollees that had annual monitoring exams, including physical health and mental health questionnaires, Fig. 1. REAP-S was implemented in the annual questionnaire on March 1, 2018 and continuously accrued until July 17, 2019. Two questions were used to gauge interest

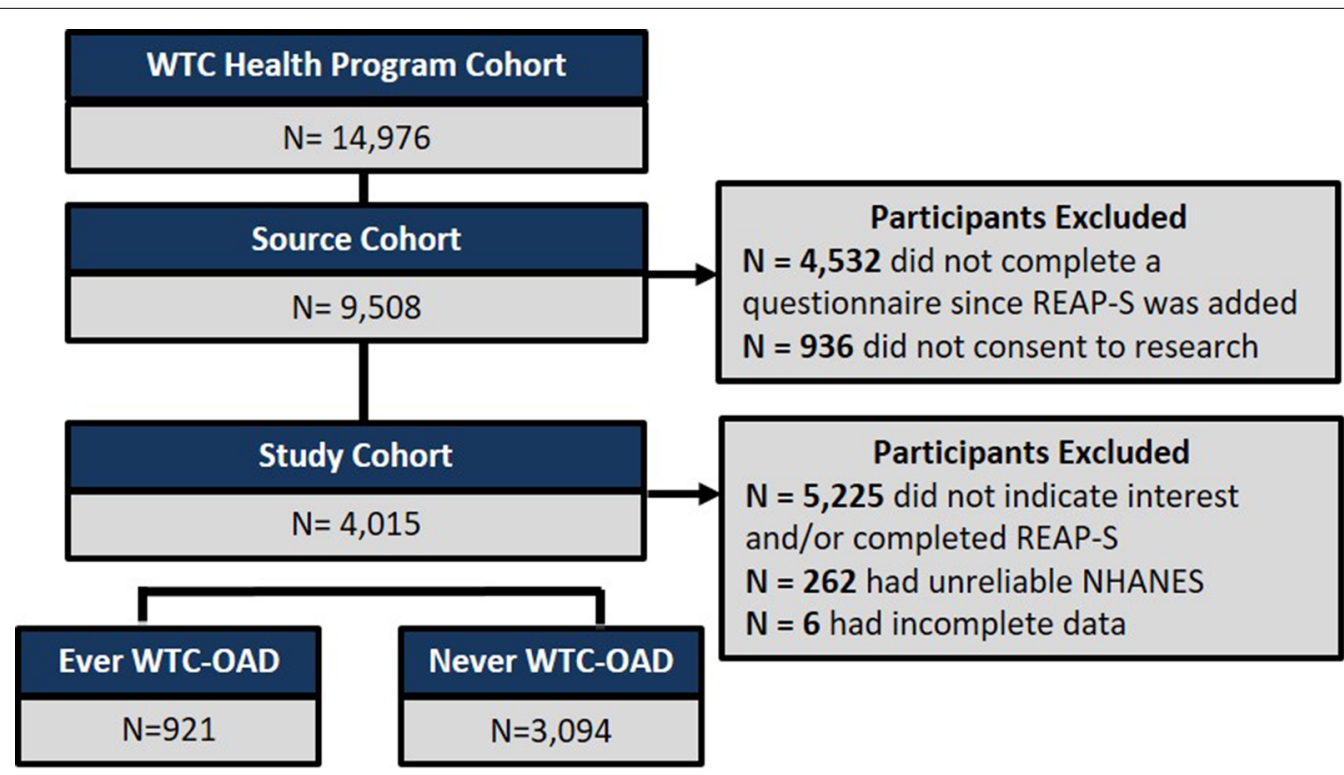

Fig. 1 Study Design/Consort Diagram. FDNY Rescue/recovery Workers Exposed to World Trade Center Particulates 
in answering the REAP-S and screen for willingness to change diet, Additional file 1: Table S1.

Source cohort $(\mathrm{N}=9508)$ completed an annual health questionnaire and consented to further physical health research. Subjects were further screened for the study cohort $(\mathrm{N}=4015)$ if they met the following criteria: (i) completed REAP-S (ii) had reliable National Health and Nutrition Examination Survey (NHANES) and (iii) had complete clinical data. Demographic characteristics, clinical data, 9/11 exposure characteristics, questionnaire answers, and lung function testing were obtained from the FDNY WTC-HP electronic medical record (EMR). Study approved by the Montefiore Medical Center/ Albert Einstein College of Medicine IRB \#07-09-320.

\section{WTC-OAD case definitions}

Cases of WTC-OAD had either WTC-Lung Injury (WTC-LI; FEV ${ }_{1}<\mathrm{LLN}$ ) and/or Airway Hyperresponsiveness (AHR; positive methacholine or positive bronchodilator testing) at any time point post-9/11 $(\mathrm{N}=921)[16$, $16,21,21-24,50-62]$. Cases of WTC-OAD were compared to $\mathrm{N}=3094$ without WTC-OAD at any time after 9/11.

Our group has utilized $\mathrm{FEV}_{1}$ to define WTC-LI [16, 16, 21-23, 53, 59, 60, 63-65]. $\mathrm{FEV}_{1}$ was measured prior to $9 / 11 / 2001$ and is still performed at every FDNY-HP visit. This gives a comprehensive measure of changing lung function over time. Using abnormal $\mathrm{FEV}_{1}$ as an outcome improves generalizability of our findings since it is a readily available measure that doesn't require costly instrumentation. A vast majority of the WTC cohort had airflow obstruction [51]. Deterioration of $\mathrm{FEV}_{1}<\mathrm{LLN}$ is a robust disease definition, correlates with mortality and somewhat with OAD outcomes (severity leading to hospitalizations, exercise ability and measures of quality of life measures) [66-73]. Using $\mathrm{FEV}_{1}$ as a single measure of lung function could lead to non-differential misclassification. Since $\mathrm{FEV}_{1}$ is reduced in both restriction and obstruction, $\mathrm{FEV}_{1}<\mathrm{LLN}$ does not distinguish between the two. In spite of the potential for non-differential information bias, using $\mathrm{FEV}_{1}<\mathrm{LLN}$ has yielded strong biomarkers-disease associations [74, 75]. Therefore, $\mathrm{FEV}_{1}<\mathrm{LLN}$ is a surrogate for obstruction in WTCexposed firefighters and was how we defined WTC-LI $[51,76,77]$.

\section{Nutritional assessment}

REAP-S was scored and summed as per guidelines, Table 2 and Additional file 1: Table S1 [43]. REAP-S scores can range from 15-39, and higher quantities represent dietary quality characterized by optimal intake of fruits, vegetables, and whole grains and decreased intake of sugary foods, processed meats, and fried foods. Scores were categorized into low-dietary [15-19], moderatedietary [16, 20-28], and high-dietary [29-38] quality, Table 3. Additionally, REAP-S questions were assessed as distinct food categories.

$A G E$ quantification (kU/serving) in food groups represented in REAP-S was compiled to a representative value per food group, Additional file 2: Figure S2 [78].

\section{Statistics}

Primary data storage/analyses performed with SPSS 25 (IBM) and Prism 8 (Graphpad). Mean \pm standard deviation (SD) expressed as continuous variables. Paired sample t-tests compared clinical parameters at two time points-first measurement post-9/11 and at REAP-S administration; student $\mathrm{t}$-tests compared clinical data of those with WTC-OAD to those who never developed WTC-OAD. One-way ANOVA was used in a subgroup analysis of lung function and dietary quality. Counts and percentages describe categorical variables and compared groups using $X^{2}$-test.

Arrival time and smoking was self-reported and collected through the annual questionnaires/EMR. Arrival time data, used as a proxy for WTC-particulate matter (WTC-PM) exposure, was categorized into a dichotomous variable of "arrived at the site in the morning of 9/11" or "anytime thereafter" [79]. Smoking data was dichotomous representing ever or never smokers [51, 59, 64, 76, 77, 80-85].

Modeling using Multivariable logistic regression estimated association of AGE abundancy, REAP-S scores, and the development of WTC-OAD. All models were adjusted for smoking, age at September 11, 2001, exposure intensity, BMI, and job description. We assumed that dietary habits remain relatively constant over time [8688]. Models of WTC-OAD using components of REAP-S were corrected for multiple comparisons by Bonferroni, $\mathrm{p}<0.005$. For all else, $\mathrm{p}$ was significant if $<0.05$ and omnibus testing assessed variance of data.

\section{Results \\ FDNY nutrition cohort characteristics}

There were no significant demographic differences between the source cohort $(\mathrm{N}=9508)$ and the study cohort $(\mathrm{N}=4015 / 9508 ; 42.23 \%)$. Out of the total subjects with WTC-OAD $(\mathrm{N}=921), 586$ subjects $(63.62 \%)$ had WTC-LI only, 197 subjects (21.39\%) had AHR only, and 138 subjects (14.98\%) had both WTC-LI and AHR. Within those with AHR $(\mathrm{N}=335), 126(37.61 \%)$ had a positive bronchodilator, 175 (52.24\%) had a positive methacholine, and 34 (10.15\%) had both.

Subjects with WTC-OAD were more likely to be retired, member of the emergency medical services (EMS) rather than firefighter, and exposed the morning 
of 9/11 when compared to those who never developed WTC-OAD $(\mathrm{p}<0.001)$, Table 1 . Of note, age at $9 / 11$, smoking status, and race were no different in the WTCOAD and never WTC-OAD populations, Table 1.

\section{Clinical measures}

Time to reach WTC-OAD case definition was (mean \pm SD) $6.37 \pm 7.23$ years for the study cohort. For both ever WTC-OAD cases and never WTC-OAD subjects, BMI, blood pressure, and HDL were found to be significantly higher at time of REAP-S compared to immediately post-9/11, Table 1 . Similarly, their FEV ${ }_{1 \% \text { Pred }}$, HDL, LDL, total cholesterol, and triglycerides were significantly lower at time of REAP-S, and $\mathrm{FVC}_{\% \text { Pred }}$ was not significantly different. WTC-OAD cases had significantly higher BMI, blood pressure, and triglycerides, and lower $\mathrm{FEV}_{1 \% \text { Pred }}, \mathrm{FVC}_{\% \text { Pred }}$ at 1 st post $9 / 11$ and at the time of REAP-S assessment compared to those who never developed WTC-OAD. Subjects with WTC-OAD had an elevated total cholesterol compared to those that never developed WTC-OAD at their 1st post-9/11 assessment. In contrast, at the time of the REAP-S questionnaire, those subjects with WTC-OAD had lower total cholesterol, Table 1.

\section{REAP-S questionnaire responses}

Length of time between initial post 9/11 assessment and REAP-S administration was (mean \pm SD) $16.59 \pm 0.49$ years. The study cohort had a mean \pm SD REAP-S score of $29.46 \pm 4.22$. Subjects with

Table 1 Demographic and clinical data

\begin{tabular}{|c|c|c|c|c|}
\hline \multirow[t]{2}{*}{ Measures } & \multirow{2}{*}{$\begin{array}{l}\text { Study cohort } \\
N=4015\end{array}$} & \multicolumn{2}{|l|}{ WTC-OAD } & \multirow[t]{2}{*}{$\mathrm{p}$} \\
\hline & & $\begin{array}{l}\text { Ever } \\
\mathrm{N}=921\end{array}$ & $\begin{array}{l}\text { Never } \\
N=3094\end{array}$ & \\
\hline \multicolumn{5}{|l|}{ Demographics } \\
\hline Age on 9/11 & $40.55(7.40)$ & $40.64(7.12)$ & $40.53(7.48)$ & 0.68 \\
\hline Retired at exam & 3077 (76.60\%) & 765 (83.10\%) & $2312(74.70 \%)$ & $<0.001$ \\
\hline Firefighter & $3637(90.60 \%)$ & $806(87.50 \%)$ & 2831 (91.50\%) & $<0.001$ \\
\hline Ever smokers & $1291(32.20 \%)$ & $315(34.20 \%)$ & $976(31.50 \%)$ & 0.13 \\
\hline Caucasian & $3819(95.10 \%)$ & 886 (96.20\%) & $2933(94.80 \%)$ & 0.08 \\
\hline Arrived morning of $9 / 11$ & $679(16.90 \%)$ & $183(19.90 \%)$ & $496(16 \%)$ & $<0.001$ \\
\hline \multicolumn{5}{|l|}{ 1st Post-9/11 } \\
\hline $\mathrm{FEV}_{1 \% \text { Pred }}$ & $96.92(14.02)$ & $83.93(13.10)$ & $100.79(11.78)$ & $<0.001$ \\
\hline $\mathrm{FVC}_{\% \text { Pred }}$ & $92.36(12.15)$ & $83.58(11.58)$ & 94.88 (11.09) & $<0.001$ \\
\hline $\mathrm{BMI} \mathrm{kg} / \mathrm{m}^{2}$ & $29.02(3.78)$ & $29.59(4.16)$ & $28.84(3.65)$ & $<0.001$ \\
\hline Systolic BP mmHg & $117.91(14.37)$ & $119.27(14.58)$ & $117.51(14.28)$ & $<0.001$ \\
\hline Diastolic BP mmHg & $74.15(9.26)$ & $75.01(9.40)$ & $73.89(9.20)$ & $<0.001$ \\
\hline $\mathrm{HDL} \mathrm{mg} / \mathrm{dL}$ & $48.02(11.58)$ & $47.54(11.80)$ & $48.16(11.51)$ & 0.20 \\
\hline LDL mg/dL & $126.54(36.08)$ & $127.08(34.65)$ & $126.39(36.5)$ & 0.63 \\
\hline Cholesterol (total) mg/dL & $208.72(43.89)$ & $212.07(59.80)$ & $207.73(37.84)$ & $<0.001$ \\
\hline Triglyceride mg/dL & $179.91(131.57)$ & $191.93(137.60)$ & $176.34(129.52)$ & $<0.001$ \\
\hline \multicolumn{5}{|l|}{ At REAP-S } \\
\hline $\mathrm{FEV}_{1 \% \text { Pred }}$ & $93.01(14.33)$ & $77.89(14.18)$ & $97.44(10.95)$ & $<0.001$ \\
\hline $\mathrm{FVC}_{\% \text { Pred }}$ & $91.59(12.51)$ & $80.42(12.92)$ & $94.86(10.31)^{*}$ & $<0.001$ \\
\hline $\mathrm{BMI} \mathrm{kg} / \mathrm{m}^{2}$ & $30.34(4.87)$ & $31.15(5.49)$ & $30.09(4.65)$ & $<0.001$ \\
\hline Systolic BP mmHg & $126.06(12.99)$ & $127.19(13.10)$ & $125.72(12.94)$ & $<0.001$ \\
\hline Diastolic BP mmHg & 78.70 (8.38) & $79.28(8.10)$ & $78.53(8.46)$ & 0.020 \\
\hline $\mathrm{HDL} \mathrm{mg} / \mathrm{dL}$ & $53.76(14.61)$ & $53.01(14.68)$ & $53.97(14.58)$ & 0.18 \\
\hline $\mathrm{LDL} \mathrm{mg} / \mathrm{dL}$ & $116.93(33.64)$ & $113.76(34.16)$ & $117.82(33.45)$ & 0.001 \\
\hline Cholesterol (total) mg/dL & $194.91(39.45)$ & $191.33(41.32)$ & $195.91(38.86)$ & 0.020 \\
\hline Triglyceride mg/dL & $129.16(223.39)$ & $135.54(80.60)$ & $127.38(249.01)$ & 0.46 \\
\hline
\end{tabular}

All available measures are Mean (SD) or N (\%)

p-values displayed represent comparisons between ever/never WTC-OAD by Student's t-tests

${ }^{*}$ FVC $_{\% \text { Pred }}$ for Never WTC-OAD comparing 1st Post-9/11 and REAP-S by Paired t-tests was not significant, all other measures were $p<0.05$ 
WTC-OAD had significantly lower mean REAP-S score of $28.99 \pm 4.37$ compared to those who never developed WTC-OAD with $29.60 \pm 4.17 ; \mathrm{p}<0.01$. In contrast, $50 \%$ of our study cohort often eat more than the recommended amount of meat per day (Q7), 79.30\% rarely drink sugary drinks (Q13), 48.80\% rarely eat processed meats (Q8), $48.50 \%$ rarely eat fried foods (Q9), and $46.40 \%$ rarely eat snacks (Q10), Table 2. WTC-OAD cases had significantly higher reported consumption of processed meat (Q8) and sugary drinks (Q13), and decreased intake of grain products $(\mathrm{Q} 3)$, vegetables $(\mathrm{Q} 5)$, and fried foods $(\mathrm{Q} 9)$. WTC-OAD also skipped breakfast more often (Q1), ate out more frequently $(\mathrm{Q} 2)$, and did not feel well as often to shop or cook $(\mathrm{Q} 15)(\mathrm{p}<0.05)$, Table 2.

\section{Quality of diet assessed by REAP-S}

Low-dietary quality was significantly associated with 2.67 odds $(95 \%$ CI $[1.57,4.52]$; $\mathrm{p}<0.01)$ of developing WTCOAD whereas moderate-dietary quality was associated with 1.22 odds $(95 \% \mathrm{CI}[1.05,1.42] ; \mathrm{p}=0.01)$, when comparing to high-dietary quality as a reference group, Fig. 2. Increasing BMI had a small but significant protective odds ratio of 0.97 (95\% CI [0.95, 0.98]; $\mathrm{p}<0.01)$. Job description was significant, at 1.60 odds (95\% CI [1.26, 2.03]; $\mathrm{p}<0.01)$. Exposure intensity was a time-dependent risk factor, with 1.29 odds (95\% CI $[1.07,1.56] ; \mathrm{p}=0.01$ ). Age at $9 / 11$ and smoking were not significant risk factors in this model. Overall, job description, exposure, and BMI were found to have significant odds of developing WTC-OAD, while age at 9/11 and smoking were not, Fig. 2.

Dietary quality subgroups and lung function of those with low-, moderate-, or high-dietary quality are shown in Table 3. Mean $\mathrm{FEV}_{1 \% \text { Pred }}$ and $\mathrm{FVC}_{1 \% \text { Pred }}$ at both time points are significantly higher in those with higher dietary quality compared to those with lower dietary quality $(\mathrm{p}<0.05) . \mathrm{FEV}_{1} / \mathrm{FVC}$ ratio was not significantly associated with dietary quality at either timepoint, Table 3.

\section{Processed meat, sugary drinks, and vegetable intake impacted the odds of developing WTC-OAD}

Assessment of individual REAP-S questions highlighted that WTC-OAD was more likely in subjects with increased consumption of processed meats (Q8) and sugary drinks (Q13), and decreased intake of vegetables (Q5), Table 2 and Fig. 3. Additionally, there was a dose response seen with increasing intake of processed meats (OR 1.64 (95\% CI $[1.23,2.19] ; \mathrm{p}=0.001)$ and $1.27(95 \%$ CI $[1.08,1.48] ; \mathrm{p}=0.003)$ ) and less vegetables (OR 1.53 (95\% CI $[1.24,1.90] ; \mathrm{p}<0.001)$ and 1.31 (95\% CI [1.12, $1.55] ; \mathrm{p}=0.001)$ ). Less whole grain consumption is also associated with higher risk of WTC-OAD (Q3), 1.26 $(95 \%$ CI $[1.08,1.46] ; \mathrm{p}=0.004)$. WTC-OAD subjects trended towards increased fried food intake but these measures were not significant after Bonferroni correction $(\mathrm{p}=0.006)$, Table 2 and Fig. 3 .

\section{Dietary habit assessment showed that not being well enough to cook, skipping breakfast, and eating out increase odds of WTC-OAD}

Not feeling well enough to cook (Q15) increased odds of developing WTC-OAD by 1.91 (95\% CI [1.33, 2.73]; $\mathrm{p}<0.001)$ whereas skipping breakfast (Q1) was $1.20(95 \%$ CI $[1.04,1.40] ; \mathrm{p}=0.015)$. Eating out (Q2) also had odds of 1.25 (95\% CI [1.08, 1.45]; $\mathrm{p}=0.003)$, Table 2.

\section{AGE rich foods confer a higher likelihood of developing WTC-OAD}

Using data adapted from Uribarri et al., we summarized the amount of AGE in food groups represented in REAP-S, Additional file 2: Figure S1 [78]. Fried foods (3971.86 kU/serving), processed meats $(3925.89 \mathrm{kU} / \mathrm{serv}$ ing), and meats ( $3687.58 \mathrm{kU} /$ serving) were identified as having the highest AGEs per serving. Sugary foods and drinks (7.2 kU/serving) do not naturally have high level of AGEs but instead cause high levels of endogenous AGEs. Frequency of eating foods highest in AGEs, meat (Q7), processed meats $(\mathrm{Q} 8)$, and fried foods $(\mathrm{Q} 9)$, was assessed by logistic regression model adjusted for age, smoking, BMI, exposure, and job description. An AGE-rich exposure response gradient was identified with the odds of developing WTC-OAD: not significantly increased in participants answering usual/often consumption of one AGE-rich food group, significantly increased in participants answering usual/often consumption to any two AGE-rich food groups, 1.50 (95\% CI [1.14, 1.97]; $\mathrm{p}=0.04$ ), and highly significant in those answering usual/ often consumption to all three AGE-rich food groups, 2.31 (95\% CI [1.35, 3.95]; $\mathrm{p}=0.002)$, Fig. 4.

\section{Discussion}

This observational, prospective study of dietary phenotyping was successfully implemented at the FDNY WTC-HP annual monitoring exam. Dietary quality was correlated to $\mathrm{FEV}_{1}$ and $\mathrm{FVC}$ even immediately after 9/11, and persisted at REAP-S. Since we assume that diet is constant throughout adult life, this could be due to the combined effect of dietary quality and WTC exposure. This is supported by our findings in which more frequent consumption of sugary drinks, processed meats, and decreased intake of vegetables and whole grains were identified as key components in development of WTCOAD. Subjects with AGE-rich diets were also significantly more likely to develop WTC-OAD.

Our findings parallel prior studies that have displayed the harmful role of processed meats in the increased 
Table 2 Nutrition Questions Incorporated into the WTC-HP Annual Questionnaire

\begin{tabular}{|c|c|c|c|c|}
\hline Item & All & Ever WTC-OAD & Never WTC-OAD & p \\
\hline \multicolumn{5}{|c|}{ 1. How willing are you to make changes in your eating habits in order to be healthier? ${ }^{a}$} \\
\hline \multicolumn{5}{|l|}{ Very willing } \\
\hline 2 & $1105(27.5)$ & $239(26)$ & $866(28)$ & \\
\hline 3 & $6565(16.3)$ & $173(18.8)$ & $483(15.6)$ & \\
\hline 4 & $110(2.7)$ & $22(2.4)$ & $88(2.8)$ & \\
\hline $\begin{array}{l}5 \\
\text { Not at all willing }\end{array}$ & $49(1.2)$ & $14(1.5)$ & $35(1.1)$ & \\
\hline \multicolumn{5}{|c|}{ 2. Are you willing to answer 15 questions about your diet? ${ }^{b}$} \\
\hline Yes & $4015(100)$ & - & - & - \\
\hline \multicolumn{5}{|l|}{ In an average week, how often do you: } \\
\hline \multicolumn{5}{|l|}{ 1. Skip breakfast? } \\
\hline Usually/often (1) & $839(20.9)$ & $215(23.3)$ & $624(20.2)$ & \multirow[t]{3}{*}{0.030} \\
\hline Sometimes (2) & $1180(29.4)$ & $281(30.5)$ & $899(29.1)$ & \\
\hline Rarely/never (3) & $1996(49.7)$ & $425(46.1)$ & $1571(50.8)$ & \\
\hline \multicolumn{5}{|c|}{ 2. Eat 4 or more meals from sit-down or take out restaurants? } \\
\hline Usually/often (1) & $532(13.3)$ & $135(14.5)$ & $398(12.9)$ & \multirow[t]{3}{*}{0.016} \\
\hline Sometimes (2) & $1182(29.4)$ & $297(32.3)$ & $885(28.6)$ & \\
\hline Rarely/never (3) & $2301(57.3)$ & $490(53.2)$ & $1811(58.5)$ & \\
\hline \multicolumn{5}{|c|}{$\begin{array}{l}\text { 3. Eat less than } 2 \text { servings of whole grain products or high fiber starches a day? Serving }=1 \text { slice of } 100 \% \text { whole grain bread; } 1 \text { cup whole grain cereal } \\
\text { like Shredded Wheat, Wheaties, Grape Nuts, high fiber cereals, oatmeal, 3-4 whole grain crackers, } 12 \text { cup brown rice or whole wheat pasta, boiled or } \\
\text { baked potatoes, yuca, yams or plantain }\end{array}$} \\
\hline Usually/often (1) & $744(18.5)$ & $176(19.1)$ & $568(18.4)$ & \multirow[t]{3}{*}{0.016} \\
\hline Sometimes (2) & $1624(40.4)$ & $404(43.9)$ & $1220(39.4)$ & \\
\hline Rarely/never (3) & $1647(41)$ & $341(37)$ & $1306(42.2)$ & \\
\hline \multicolumn{5}{|c|}{ 4. Eat less than 2 servings of fruit a day? Serving $=1 / 2$ cup or 1 med. fruit or $3 / 4$ cup $100 \%$ fruit juice } \\
\hline Usually/often (1) & $1016(25.3)$ & $246(26.7)$ & $770(24.9)$ & \multirow[t]{3}{*}{0.191} \\
\hline Sometimes (2) & $1682(41.9)$ & $395(42.9)$ & $1287(41.6)$ & \\
\hline Rarely/never (3) & $1317(32.8)$ & $280(30.4)$ & $1037(33.5)$ & \\
\hline \multicolumn{5}{|c|}{ 5. Eat less than 2 servings of vegetables a day? Serving $=1 / 2$ cup vegetables, or 1 cup leafy raw vegetables } \\
\hline Usually/often (1) & $618(15.4)$ & $169(18.3)$ & $449(14.5)$ & \multirow[t]{3}{*}{$<0.001$} \\
\hline Sometimes (2) & $1603(39.9)$ & $394(42.8)$ & $1209(39.1)$ & \\
\hline Rarely/never (3) & $1794(44.7)$ & $358(38.9)$ & $1436(46.4)$ & \\
\hline \multicolumn{5}{|c|}{ 6. Eat or drink less than 2 servings of milk, yogurt, or cheese a day? Serving $=1$ cup milk or yogurt; $1 \frac{1}{2}-2$ oz cheese } \\
\hline Usually/often (1) & $826(20.6)$ & $209(22.7)$ & $617(19.9)$ & \multirow[t]{3}{*}{0.125} \\
\hline Sometimes (2) & $1491(37.1)$ & $344(37.4)$ & $1147(37.1)$ & \\
\hline Rarely/never (3) & $1698(42.3)$ & $368(40)$ & $1330(43)$ & \\
\hline \multicolumn{5}{|c|}{$\begin{array}{l}\text { 7. Eat more than } 8 \text { oz (see sizes below) of meat, chicken, turkey or fish per day? Note: } 3 \text { oz of meat or chicken is the size of a deck of cards or ONE of } \\
\text { the following: } 1 \text { regular hamburger, } 1 \text { chicken breast or leg (thigh and drumstick), or } 1 \text { pork chop }\end{array}$} \\
\hline Usually/often (1) & $2008(50)$ & $468(50.8)$ & $1540(49.8)$ & \multirow[t]{3}{*}{0.705} \\
\hline Sometimes (2) & $1450(36.1)$ & $322(35)$ & $1128(36.5)$ & \\
\hline $\begin{array}{l}\text { Rarely/never or rarely eat meat, chicken, } \\
\text { turkey or fish (3) }\end{array}$ & $557(13.9)$ & $131(14.2)$ & $426(13.8)$ & \\
\hline \multicolumn{5}{|c|}{$\begin{array}{l}\text { 8. Use regular processed meats (like bologna, salami, corned beef, hotdogs, sausage or bacon) instead of low fat processed meats (like roast beef, } \\
\text { turkey, lean ham; low-fat cold cuts/hotdogs)? }\end{array}$} \\
\hline Usually/often (1) & $271(6.7)$ & $80(8.7)$ & $191(6.2)$ & \multirow[t]{3}{*}{0.001} \\
\hline Sometimes (2) & $1784(44.4)$ & $432(46.9)$ & $1352(43.7)$ & \\
\hline Rarely/never or rarely (3) & $1960(48.8)$ & $409(44.4)$ & $1551(50.1)$ & \\
\hline
\end{tabular}

risk of developing COPD due to its high level of proinflammatory AGE levels [89-92]. AGE formation via glycoxidation is promoted by the high temperatures and low moisture environments utilized in cooking meat, 
Table 2 (continued)

\begin{tabular}{|c|c|c|c|c|}
\hline Item & All & Ever WTC-OAD & Never WTC-OAD & $\mathbf{p}$ \\
\hline \multicolumn{5}{|c|}{ 9. Eat fried foods such as fried chicken, fried fish, French fries, fried plantains, tostones or fried yuca? } \\
\hline Usually/often (1) & $174(4.3)$ & $54(5.9)$ & $120(3.9)$ & \multirow[t]{3}{*}{0.024} \\
\hline Sometimes (2) & 1895 (47.2) & $417(45.3)$ & $1478(47.8)$ & \\
\hline Rarely/never (3) & $1946(48.5)$ & $450(48.9)$ & $1496(48.4)$ & \\
\hline \multicolumn{5}{|c|}{$\begin{array}{l}\text { 10. Eat regular potato chips, nacho chips, corn chips, crackers, regular popcorn, nuts instead of pretzels, low-fat chips or lowfat crackers, air-popped } \\
\text { popcorn? }\end{array}$} \\
\hline Usually/often (1) & $338(8.4)$ & $79(8.6)$ & $259(8.4)$ & \multirow[t]{3}{*}{0.111} \\
\hline Sometimes (2) & $1815(45.2)$ & $389(42.2)$ & $1426(46.1)$ & \\
\hline $\begin{array}{l}\text { Rarely/never or Rarely eat these snack } \\
\text { foods (3) }\end{array}$ & $1862(46.4)$ & $453(49.2)$ & $1409(45.5)$ & \\
\hline \multicolumn{5}{|c|}{ 11. Add butter, margarine or oil to bread, potatoes, rice or vegetables at the table? } \\
\hline Usually/often (1) & $1059(26.4)$ & $252(27.4)$ & $807(26.1)$ & \multirow[t]{3}{*}{0.290} \\
\hline Sometimes (2) & $1619(40.3)$ & $382(41.5)$ & $1237(40)$ & \\
\hline Rarely/never (3) & $1337(33.3)$ & $287(31.2)$ & $1050(33.9)$ & \\
\hline \multicolumn{5}{|c|}{ 12. Eat sweets like cake, cookies, pastries, donuts, muffins, chocolate and candies more than 2 times per day } \\
\hline Usually/often (1) & $678(16.9)$ & $165(17.9)$ & $513(16.6)$ & \multirow[t]{3}{*}{0.432} \\
\hline Sometimes (2) & $1676(41.7)$ & $369(40.1)$ & $1307(42.2)$ & \\
\hline Rarely/never (3) & $1661(41.4)$ & $387(42)$ & $1274(41.2)$ & \\
\hline \multicolumn{5}{|c|}{ 13. Drink $16 \mathrm{oz}$ or more of non-diet soda, fruit drink/punch or Kool-Aid a day? Note: 1 can of soda $=12 \mathrm{oz}$} \\
\hline Usually/often (1) & $259(6.5)$ & $72(7.8)$ & $187(6)$ & \multirow[t]{3}{*}{0.001} \\
\hline Sometimes (2) & $573(14.3)$ & $159(17.3)$ & $414(13.4)$ & \\
\hline Rarely/never (3) & $3183(79.3)$ & $690(74.9)$ & $2493(80.6)$ & \\
\hline \multicolumn{5}{|c|}{ 14. You or a member of your family usually shops and cooks rather than eating sit-down or take-out restaurant food? } \\
\hline Yes & $3673(91.5)$ & $831(90.2)$ & $2842(91.9)$ & 0.120 \\
\hline \multicolumn{5}{|c|}{ 15. Usually feel well enough to shop or cook } \\
\hline Yes & $3876(96.5)$ & $872(94.7)$ & $3004(97.1)$ & $<0.001$ \\
\hline
\end{tabular}

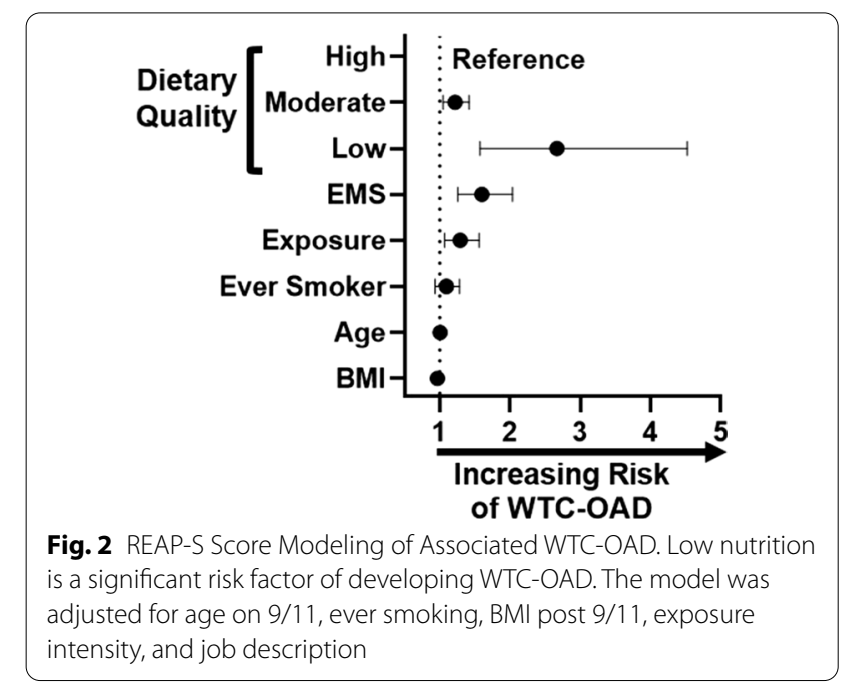

processed meat products, and fried foods [78, 93-95]. Associations with certain food groups are important because high levels of AGEs are linked to pathogenic effects, including the ability to promote high levels of oxidative stress and inflammation [78, 94].

Although sugary drinks are relatively low in AGEs, they are a prominent source of high fructose corn syrup [27]. The fructose can indirectly increase AGE intake because of its formation and accumulation of endogenous AGEs [27]. This could be a reason as to why sugary drinks have been associated with bronchitis and asthma in children, and increase likelihood of WTCOAD [96, 97]. In contrast, carbohydrates and whole grains contain less AGE $[78,95]$. Similar to our results, other studies have found that increased whole grain intake, part of a prudent dietary pattern, were associated with a reduced risk of developing COPD [13]. Moreover, it was positively associated with $\mathrm{FEV}_{1}$ and negatively associated with COPD symptoms [98]. 
Table 3 Dietary quality subgroup analysis

\begin{tabular}{|c|c|c|c|c|c|}
\hline \multirow[t]{2}{*}{ Time } & \multirow[t]{2}{*}{ Spirometry } & \multicolumn{3}{|c|}{ Dietary quality } & \multirow[t]{2}{*}{$p$} \\
\hline & & $\operatorname{Low}(\mathrm{N}=61)$ & Moderate $(\mathrm{N}=1894)$ & High $(N=2060)$ & \\
\hline \multirow[t]{3}{*}{ 1st Post-9/11 } & FEV $_{1 \% \text { Pred }}$ & $93.57(15.34)$ & $96.28(14.01)$ & $97.61(13.94)$ & $<0.01$ \\
\hline & $\mathrm{FVC}_{\% \text { Pred }}$ & $90.30(13.28)$ & $91.95(12.15)$ & $92.81(12.09)$ & 0.04 \\
\hline & $\mathrm{FEV}_{1} / \mathrm{FVC}$ & $0.83(0.05)$ & $0.84(0.06)$ & $0.84(0.06)$ & 0.79 \\
\hline \multirow[t]{3}{*}{ REAP-S } & $\mathrm{FEV}_{1 \% \text { Pred }}$ & $86.45(19.87)$ & $91.95(14.28)$ & $94.12(14.08)$ & $<0.001$ \\
\hline & $F V C_{\% \text { Pred }}$ & $85.82(14.86)$ & $90.58(12.32)$ & $92.64(12.51)$ & $<0.001$ \\
\hline & $\mathrm{FEV}_{1} / \mathrm{FVC}$ & $0.77(0.08)$ & $0.77(0.06)$ & $0.77(0.05)$ & 0.46 \\
\hline
\end{tabular}

All values displayed as mean(SD). $p$-value calculated by ANOVA

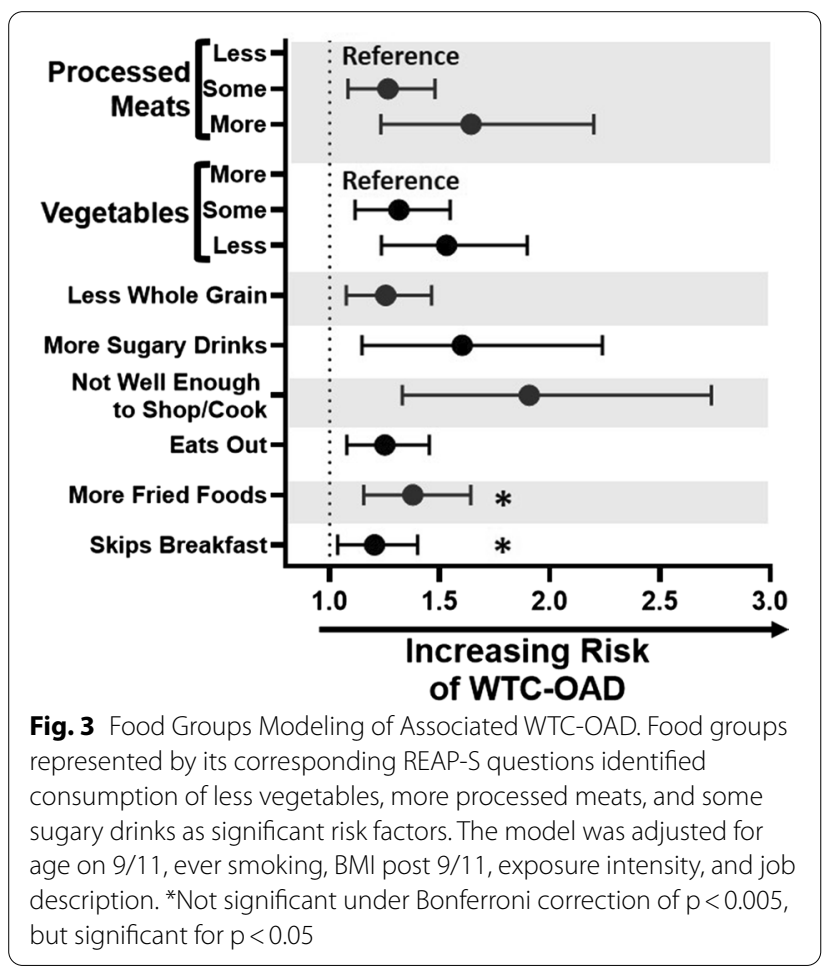

Although we showed that low intake of vegetables increased odds of developing WTC-OAD, there was no significant association found with fruit intake. While our results resonated with some studies on low intake of fruits and vegetables, others advocated for increased fruit intake, or found no difference in COPD [78, 99-104]. Although fruits and vegetables are relatively low in AGEs, they could confer antioxidant benefit and lower inflammation in diseases such as COPD. A randomized control trial focused on increased antioxidant intake through fruits and vegetables found that it could even help regain $\mathrm{FEV}_{1}$ in COPD patients [102].

In contrast to our prior work, increasing BMI had a $3.6 \%$ decreased likelihood of developing WTC-OAD.

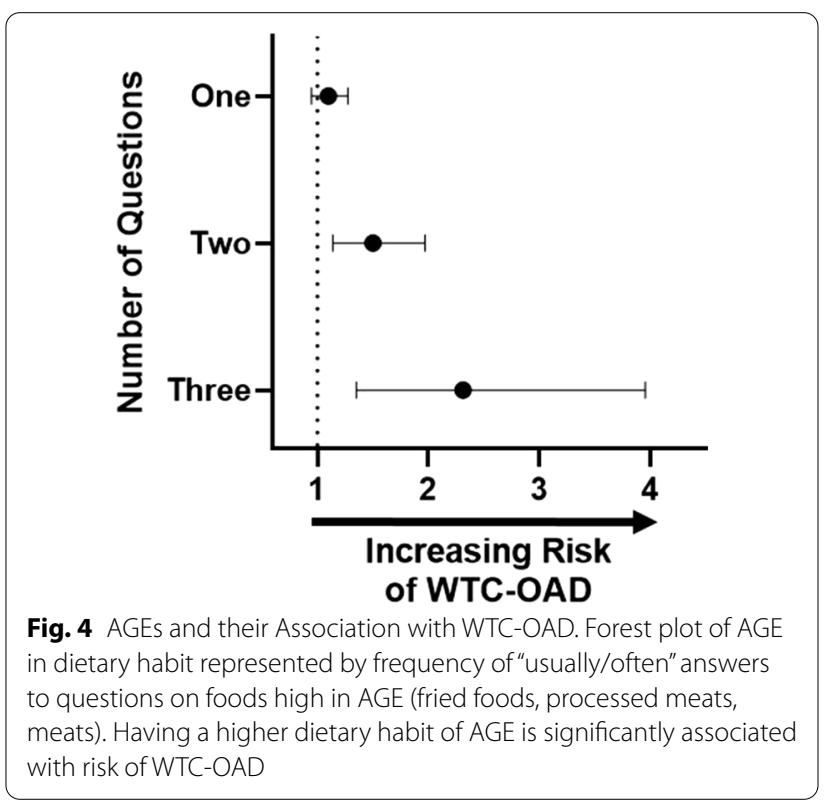

One reason for this difference could be that while our prior work focused on firefighters, we now also investigate EMS 1st responders. Prior studies have shown that the firefighter and EMS cohort express different patterns of lung function decline, even after adjusting for BMI [18]. This expanded cohort potentially reflects concordance with studies showing obesity's protective effect against mortality in COPD patients $[105,106]$. This could also be a result of a healthy worker effect and the imperfect utilization of BMI to define obesity in firefighters with rigorous physical job requirements [107]. In addition, we optimized our model by adjusting for confounding of WTC-OAD cases by using BMI at the time of diagnosis, whereas for subjects that never developed WTC-OAD, BMI at REAP-S was used. Nevertheless, the results of the final model did not change significantly even when we also assessed the effects of BMI at the same time point (1st post 9/11 and at REAP$\mathrm{S}$ respectively). Moroever, we found that triglycerides 
decreased from post 9/11 to REAP-S. This could be an effect of the close monitoring that these patients received and/or other confounder such as triglyceridelowering medications such as statin therapy in as per 2018 American Heart Association/American College of Cardiology guidelines [108]. Future studies could help differentiate the paradoxical effect of obesity vs. the healthy worker phenomena.

There are several limitations to our investigation. Dietary habits and exposure are subject to self-reporting bias. Bias assessment has been performed on the FDNY WTC cohort, and found that self-reported asthma and exposure were consistent across several studies, and that significant findings were minimally affected by potential bias [109]. Thus, extension of the reliability of this data to our study is reasonable. We also assume that dietary habits remain relatively constant throughout a person's adult life, an assumption supported by several large studies $[86,88,110]$. Additionally, REAP-S is a brief dietary instrument that limits our ability to differentiate subtypes of food consumed. Protein intake does not differentiate between beans, poultry, or red meat. Firefighters had preemployment physical health assessments to ensure that they did not have pre-existing OAD, the pulmonary function for EMS prior to 9/11 was also assessed but these 1st responders are not subject to the same standards. Therefore, our results are limited to correlation of dietary quality and OAD.

Another possible limitation is that WTC-OAD subjects were more likely to be retired compared to those who never developed WTC-OAD. We also identified that not being well enough to shop and cook and frequent eating out had strong associations with WTC-OAD. Since this was assessed at a later time point, it is unclear if this reflects the burden of concurrent WTC-OAD. One study has found that physical factors with COPD patients such as being too tired to cook resulted in the shift in eating meals that have been easily prepared [111]. However, this is an important finding that highlights a potential barrier to access to healthier diets in this population. The limiting lifestyle imposed by WTC-OAD could further perpetuate an unforgiving cycle of lower dietary quality and worsening disease.

This study identifies risk factors of worsening OAD, and demonstrates the potential for intervention. Further research is needed to determine if implementation of a diet focused on decreasing AGE-rich foods, increasing antioxidant intake, and targeting weight loss could prevent the development of WTC-OAD or in those with WTC-OAD, reverse or slow its progression. Our ongoing randomized clinical trial, the Food Intake Restriction for Health Outcome Support and Education (FIREHOUSE) Trial, aims to assess the effects of technology-assisted social cognitive behavioral therapy and a low-caloric Mediterranean diet on the progression of WTC-LI.

In summary, this observational study successfully used REAP-S to identify both low-dietary quality and AGE abundant foods as predictive of developing lung disease in this WTC-exposed population. Our findings indicate the potential impact of future research using dietary interventions not just in the FDNY WTC-HP, but also in other OAD cohorts, with or without WTC-exposure.

\section{Supplementary Information}

The online version contains supplementary material available at https://doi. org/10.1186/s12931-020-01596-6.

Additional file 1: Table S1. Full Nutrition Questions. All of the nutrition questions that were incorporated into the WTC-HP annual questionnaire.

Additional file 2: Figure S1. Assessment of AGEs in REAP-S Food Groups. REAP-S identified food groups (fried foods, processed meats, and meats) that have the highest amounts of AGE (kU/serving) adapted from Uribarri et al. [78]

\section{Abbreviations}

AGE: Advanced glycation end-products; AHR: Airway hyperreactivity; BMI: Body Mass Index; Cl: Confidence interval; DBP: Diastolic blood pressure; EMS: Emergency Medical Services; FDNY: Fire Department of the City of New York: $\mathrm{FEV}_{1}$ : Forced expiratory volume over $1 \mathrm{~s}$; FFQ: Food Frequency Questionnaire FVC: Forced vital capacity; HDL: High density lipoprotein; HR: Hazards ratio; LDL: Low density lipoprotein; LLN: Lower limit of normal; MetSyn: Metabolic syndrome; NHANES: National Health and Nutrition Examination Survey; OR: Odds ratio; PFT: Pulmonary function test; PM: Particulate matter; PUFA: Polyunsaturated fatty acids; REAP-S: Rapid Eating and Activity Assessment for Patients-Short Version; SBP: Systolic blood pressure; SD: Standard deviation; US: United States; WTC: World Trade Center; WTC-HP: WTC-Health Program; WTC-LI: WTC-Lung Injury; WTC-OAD: WTC-obstructive airways disease; WTCPM: WTC-particulate matter.

\section{Acknowledgements}

We would like to thank the FDNY first responders for their bravery, sacrifice and continued commitment.

\section{Authors' contributions}

$\mathrm{RL}, \mathrm{AN}$ and SK participated in study conception and design; $A N$ was the primary investigator and guarantor of the paper; RL, AN, SK, HC, AH, TS, RZO and DJP were responsible for data collection; $A N$ and SK were responsible for data validation; RL, AN, SK, and GC participated in data analysis; $A N, G C, M L$, and SK undertook the statistical analysis. All authors participated in data interpretation, writing, and revision of the report and approval of the final version. All authors read and approved the final manuscript.

\section{Funding}

NHLBI R01HL119326, CDC/NIOSH U01-OH11300, Clinical Center of Excellence 200-2017-93426, Data Center 200-2017-93326.

\section{Availability of data and materials}

Sharing of human data is governed by the World Trade Center (WTC) Clinical Center of Excellence program maintained by the Fire Department of New York (FDNY). All investigators will need to enter into a data use agreement with the FDNY WTC Clinical Center of Excellence. Additional information about this database may be obtained through Dr. David Prezant. He can be reached by email at prezand@fdny.nyc.gov.

\section{Ethics approval and consent to participate}

The authors declare no competing interests. Study approved by the Montefiore Medical Center/Albert Einstein College of Medicine IRB \#07-09-320. 


\section{Competing interests}

The authors report no conflicts of interest.

\section{Author details}

${ }^{1}$ Department of Medicine, Division of Pulmonary, Critical Care and Sleep Medicine, New York University, School of Medicine, New York, NY, USA. ${ }^{2}$ Division of Biostatistics, Departments of Population Health, New York University School of Medicine, New York, NY, USA. ${ }^{3}$ Fire Department of New York, Bureau of Health Services, Brooklyn, NY, USA. ${ }^{4}$ Pulmonary Medicine Division, Department of Medicine, Montefiore Medical Center and Albert Einstein College of Medicine, Bronx, NY, USA. ${ }^{5}$ Department of Environmental Medicine, New York University, School of Medicine, New York, NY, USA. ${ }^{6}$ Department of Medicine, Division of Pulmonary, Critical Care and Sleep, New York University, School of Medicine, New Bellevue, 16 S Room 16 (Office), 16N Room 20 (Lab), 4621 st Avenue, New York, NY 10016, USA.

Received: 9 July 2020 Accepted: 3 December 2020

Published online: 18 January 2021

\section{References}

1. Hanson C, Rutten EP, Wouters EF, Rennard S. Influence of diet and obesity on COPD development and outcomes. Int J Chron Obstruct Pulmon Dis. 2014;9:723-33.

2. Wood LG. Diet, obesity, and asthma. Ann Am Thorac Soc. 2017;14(Supplement_5):S332-8.

3. Napier CO, Mbadugha O, Bienenfeld LA, Doucette JT, Lucchini R, Luna-Sanchez $S$, et al. Obesity and weight gain among former World Trade Center workers and volunteers. Arch Environ Occup $\mathrm{H}$. 2017;72(2):106-10.

4. Guo WA, Davidson BA, Ottosen J, Ohtake PJ, Raghavendran K, Mullan BA, et al. Effect of high advanced glycation end-product diet on pulmonary inflammatory response and pulmonary function following gastric aspiration. Shock. 2012;38(6):677-84

5. DeChristopher LR, Uribarri J, Tucker KL. Intake of high fructose corn syrup sweetened soft drinks is associated with prevalent chronic bronchitis in U.S. Adults, ages 20-55 y. Nutr J. 2015;14:107.

6. Zheng PF, Shu L, Si CJ, Zhang XY, Yu XL, Gao W. Dietary patterns and chronic obstructive pulmonary disease: a meta-analysis. COPD. 2016;13(4):515-22.

7. Scoditti E, Massaro M, Garbarino S, Toraldo DM. Role of diet in chronic obstructive pulmonary disease prevention and treatment. Nutrients. 2019;11(6):1357.

8. Hakala K, Stenius-Aarniala B, Sovijarvi A. Effects of weight loss on peak flow variability, airways obstruction, and lung volumes in obese patients with asthma. Chest. 2000;118(5):1315-21.

9. Shai I, Schwarzfuchs D, Henkin Y, Shahar DR, Witkow S, Greenberg I, et al. Weight loss with a low-carbohydrate, Mediterranean, or low-fat diet. N Engl J Med. 2008;359(3):229-41.

10. Schwartz J. Role of polyunsaturated fatty acids in lung disease. Am J Clin Nutr. 2000;71(1 Suppl):393S-S396.

11. Seegmiller AC. Abnormal unsaturated fatty acid metabolism in cystic fibrosis: biochemical mechanisms and clinical implications. Int J Mol Sci. 2014;15(9):16083-99.

12. Varraso R, Fung TT, Barr RG, Hu FB, Willett W, Camargo CA Jr. Prospective study of dietary patterns and chronic obstructive pulmonary disease among US women. Am J Clin Nutr. 2007;86(2):488-95.

13. Varraso R, Fung TT, Hu FB, Willett W, Camargo CA. Prospective study of dietary patterns and chronic obstructive pulmonary disease among US men. Thorax. 2007;62(9):786-91.

14. Webber MP, Yip J, Zeig-Owens R, Moir W, Ungprasert P, Crowson CS, et al. Post-9/11 sarcoidosis in WTC-exposed firefighters and emergency medical service workers. Respir Med. 2017;132:232-7.

15. Long NP, Park S, Anh NH, Nghi TD, Yoon SJ, Park JH, et al. High-throughput omics and statistical learning integration for the discovery and validation of novel diagnostic signatures in colorectal cancer. Int J Mol Sci. 2019;20(2):296.

16. Kwon S, Crowley G, Mikhail M, Lam R, Clementi E, Zeig-Owens R, et al. Metabolic syndrome biomarkers of World Trade Center Airway
Hyperreactivity: a 16-year prospective cohort study. Int J Environ Res Public Health. 2019;16(9):1486.

17. Chen JC, Schwartz J. Metabolic syndrome and inflammatory responses to long-term particulate air pollutants. Environ Health Perspect. 2008;116(5):612-7.

18. Aldrich TK, Gustave J, Hall CB, Cohen HW, Webber MP, Zeig-Owens R, et al. Lung function in rescue workers at the World Trade Center after 7 years. N Engl J Med. 2010;362(14):1263-72.

19. Webber MP, Lee R, Soo J, Gustave J, Hall CB, Kelly K, et al. Prevalence and incidence of high risk for obstructive sleep apnea in World Trade Center-exposed rescue/recovery workers. Sleep Breath. 2011;15(3):283-94.

20. Kwon S, Crowley G, Haider SH, Lam R, Zhang L, Zeig-Owens R, et al. Weight loss as a modifiable risk: Body Mass Index and loss of lung function in World Trade Center Particulate Exposure. Am J Respir Crit Care Med. 2017.

21. Crowley G, Kwon S, Haider SH, Caraher EJ, Lam R, St-Jules DE, et al. Metabolomics of World Trade Center-Lung Injury: a machine learning approach. BMJ Open Respir Res. 2018;5(1):e000274.

22. Crowley G, Kwon S, Ostrofsky DF, Clementi EA, Haider SH, Caraher EJ, et al. Assessing the protective metabolome using machine learning in World Trade Center particulate exposed firefighters at risk for lung injury. Sci Rep. 2019a;9(1):11939.

23. Kwon S, Crowley G, Caraher EJ, Haider SH, Lam R, Veerappan A, et al. Validation of predictive metabolic syndrome biomarkers of World Trade Center Lung Injury: a 16-year longitudinal study. Chest. 2019;156(3):486-96.

24. Caraher EJ, Kwon S, Haider SH, Crowley G, Lee A, Ebrahim M, et al. Receptor for advanced glycation end-products and World Trade Center particulate induced lung function loss: a case-cohort study and murine model of acute particulate exposure. PLoS ONE. 2017;12(9):e0184331.

25. Veerappan A, Oskuei A, Crowley G, Mikhail M, Ostrofsky D, Gironda Z, et al. World Trade Center-cardiorespiratory and vascular dysfunction: assessing the phenotype and metabolome of a murine particulate matter exposure model. Sci Rep. 2020;10(1):3130.

26. Haider SH, Veerappan A, Crowley G, Ostrofsky D, Mikhail M, Lam R, et al. MultiOMICs of WTC-particulate induced persistent airway hyperreactivity: role of receptor for advanced glycation end products. Am J Respir Cell Mol Biol. 2020.

27. Aragno M, Mastrocola R. Dietary sugars and endogenous formation of advanced glycation endproducts: emerging mechanisms of disease. Nutrients. 2017:9(4):385.

28. Spelta F, Fratta Pasini AM, Cazzoletti L, Ferrari M. Body weight and mortality in COPD: focus on the obesity paradox. Eat Weight Disord. 2018;23(1):15-22.

29. Guo Y, Zhang T, Wang Z, Yu F, Xu Q, Guo W, et al. Body mass index and mortality in chronic obstructive pulmonary disease: a dose-response meta-analysis. Medicine (Baltimore). 2016;95(28):e4225.

30. Kline CE, Crowley EP, Ewing GB, Burch JB, Blair SN, Durstine JL, et al. Blunted heart rate recovery is improved following exercise training in overweight adults with obstructive sleep apnea. Int J Cardiol. 2013;167(4):1610-5.

31. de Batlle J, Barreiro E, Romieu I, Mendez M, Gomez FP, Balcells E, et al. Dietary modulation of oxidative stress in chronic obstructive pulmonary disease patients. Free Radic Res. 2010;44(11):1296-303.

32. de Batlle J, Romieu I, Anto JM, Mendez M, Rodriguez E, Balcells E, et al. Dietary habits of firstly admitted Spanish COPD patients. Respir Med. 2009;103(12):1904-10.

33. Hirayama F, Lee AH, Binns CW, Hiramatsu N, Mori M, Nishimura K. Dietary intake of isoflavones and polyunsaturated fatty acids associated with lung function, breathlessness and the prevalence of chronic obstructive pulmonary disease: possible protective effect of traditional Japanese diet. Mol Nutr Food Res. 2010;54(7):909-17.

34. Hirayama F, Lee AH, Binns CW, Zhao Y, Hiramatsu T, Tanikawa Y, et al. Do vegetables and fruits reduce the risk of chronic obstructive pulmonary disease? A case-control study in Japan. Prev Med. 2009a;49(2-3):184-9.

35. Hirayama F, Lee AH, Binns CW, Zhao Y, Hiramatsu T, Tanikawa Y, et al. Soy consumption and risk of COPD and respiratory symptoms: a casecontrol study in Japan. Respir Res. 2009b;10:56. 
36. Hirayama F, Lee AH, Oura A, Mori M, Hiramatsu N, Taniguchi H. Dietary intake of six minerals in relation to the risk of chronic obstructive pulmonary disease. Asia Pac J Clin Nutr. 2010;19(4):572-7.

37. Willett WC, Sampson L, Stampfer MJ, Rosner B, Bain C, Witschi J, et al. Reproducibility and validity of a semiquantitative food frequency questionnaire. Am J Epidemiol. 1985;122(1):51-65.

38. Rimm EB, Giovannucci EL, Stampfer MJ, Colditz GA, Litin LB, Willett WC. Reproducibility and validity of an expanded self-administered semiquantitative food frequency questionnaire among male health professionals. Am J Epidemiol. 1992;135(10):1114-26.

39. Block G, Hartman AM, Dresser CM, Carroll MD, Gannon J, Gardner L. A data-based approach to diet questionnaire design and testing. Am J Epidemiol. 1986;124(3):453-69.

40. Block G, Woods M, Potosky A, Clifford C. Validation of a self-administered diet history questionnaire using multiple diet records. J Clin Epidemiol. 1990;43(12):1327-35.

41. Gans KM, Risica PM, Wylie-Rosett J, Ross EM, Strolla LO, McMurray J, et al. Development and evaluation of the nutrition component of the Rapid Eating and Activity Assessment for Patients (REAP): a new tool for primary care providers. J Nutr Educ Behav. 2006;38(5):286-92.

42. Gans KM, Ross E, Barner CW, Wylie-Rosett J, McMurray J, Eaton C. REAP and WAVE: new tools to rapidly assess/discuss nutrition with patients. J Nutr. 2003;133(2):556S-S562

43. Segal-Isaacson CJ, Wylie-Rosett J, Gans KM. Validation of a short dietary assessment questionnaire: the Rapid Eating and Activity Assessment for Participants short version (REAP-S). Diabetes Educ. 2004;30(5):774, 6, 8 passim.

44. Kennedy ET, Ohls J, Carlson S, Fleming K. The Healthy Eating Index: design and applications. J Am Diet Assoc. 1995;95(10):1103-8.

45. McCullough ML, Willett WC. Evaluating adherence to recommended diets in adults: the Alternate Healthy Eating Index. Public Health Nutr. 2006;9(1A):152-7.

46. Varraso R, Chiuve SE, Fung TT, Barr RG, Hu FB, Willett WC, et al. Alternate Healthy Eating Index 2010 and risk of chronic obstructive pulmonary disease among US women and men: prospective study. BMJ. 2015;350:h286.

47. Sundermann EE, Katz MJ, Lipton RB, Lichtenstein AH, Derby CA. A brief dietary assessment predicts executive dysfunction in an elderly cohort: results from the einstein aging study. J Am Geriatr Soc. 2016;64(11):e131-6.

48. Ahdout J, Kotlerman J, Elashoff D, Kim J, Chiu MW. Modifiable lifestyle factors associated with metabolic syndrome in patients with psoriasis. Clin Exp Dermatol. 2012;37(5):477-83.

49. Kobayashi H, Nolan A, Naveed B, Hoshino Y, Segal LN, Fujita Y, et al. Neutrophils activate alveolar macrophages by producing caspase6-mediated cleavage of IL-1 receptor-associated kinase-M. J Immunol. 2011;186(1):403-10.

50. Kwon S, Crowley G, Caraher EJ, Haider SH, Lam R, Veerappan A, Yang L, Liu M, Zeig-Owens R, SchwartzTM, Prezant DJ. Validation of predictive metabolic syndrome biomarkers of World Trade Center Lung injury: a 16-year longitudinal study. Chest J. 2019;156:486-96.

51. Weiden MD, Ferrier N, Nolan A, Rom WN, Comfort A, Gustave J, et al. Obstructive airways disease with air trapping among firefighters exposed to World Trade Center dust. Chest. 2010;137(3):566-74.

52. Ingram JM, Auerill AF, Battersby PN, Holborn PG, Nolan PF. Suppression of hydrogen-oxygen-nitrogen explosions by fine water mist: Part 1. Burning velocity. Int J Hydrogen Energ. 2012;37(24):19250-7.

53. Haider SH, Veerappan A, Crowley G, Caraher EJ, Ostrofsky D, Mikhail M, et al. Multiomics of World Trade Center particulate matter-induced persistent airway hyperreactivity. Role of receptor for advanced glycation end products. Am J Respir Cell Mol Biol. 2020;63(2):219-33.

54. Haider SH, Oskuei A, Crowley G, Kwon S, Lam R, Riggs J, et al. Receptor for advanced glycation end-products and environmental exposure related obstructive airways disease: a systematic review. Eur Respir Rev. 2019;28(151):180096.

55. Haider SH, Kwon S, Lam R, Lee AK, Caraher EJ, Crowley G, et al. Predictive biomarkers of gastroesophageal reflux disease and Barrett's Esophagus in World Trade Center exposed firefighters: a 15 year longitudinal study. Sci Rep-UK. 2018;8:1-7.
56. Aldrich TK, Weakley J, Dhar S, Hall CB, Crosse T, Banauch Gl, et al. Bronchial reactivity and lung function after world trade center exposure. Chest. 2016;150(6):1333-40.

57. Kwon S, Crowley G, Haider SH, Zhang L, Nolan A. Nephroprotective strategies in septic shock: the VANISH trial. J Thorac Dis. 2016:8(11):E1508-10.

58. Zeig-Owens R, Nolan A, Putman B, Singh A, Prezant DJ, Weiden MD. Biomarkers of patient intrinsic risk for upper and lower airway injury after exposure to the World Trade Center atrocity. Am J Ind Med. 2016;59(9):788-94.

59. Weiden MD, Kwon S, Caraher E, Berger Kl, Reibman J, Rom WN, et al. Biomarkers of World Trade Center particulate matter exposure: physiology of distal airway and blood biomarkers that predict FEV(1) decline. Semin Respir Crit Care Med. 2015;36(3):323-33.

60. Crowley G, Kwon S, Haider S, Caraher EJ, Lam R, Liu M, et al. Metabolite and biomarker predictors of World Trade Center-lung injury: an integrated multiplatform machine learning approach. Am J Resp Crit Care. 2018;197.

61. Lam R, Haider SH, Crowley G, Caraher EJ, Ostrofsky DF, Talusan A, et al. Synergistic effect of WTC-particulate matter and lysophosphatidic acid exposure and the role of RAGE: in-vitro and translational assessment. Int J Environ Res Public Health. 2020;17(12):4318.

62. Aldrich TK, Vossbrinck M, Zeig-Owens R, Hall CB, Schwartz TM, Moir W, et al. Lung function trajectories in World Trade Center-Exposed New York City firefighters over 13 years: the roles of smoking and smoking cessation. Chest. 2016;149(6):1419-27.

63. Crowley G, Kwon S, Ostrofsky DF, Clementi EA, Haider SH, Caraher EJ, et al. Assessing the protective metabolome using machine learning in World Trade Center particulate exposed firefighters at risk for lung injury. Sci Rep. 2019b;9:11939.

64. Naveed B, Weiden MD, Kwon S, Gracely EJ, Comfort AL, Ferrier N, et al. Metabolic syndrome biomarkers predict lung function impairment: a nested case-control study. Am J Respir Crit Care Med. 2012;185(4):392-9.

65. Tsukiji J, Cho SJ, Echevarria GC, Kwon S, Joseph P, Schenck EJ, et al. Lysophosphatidic acid and apolipoprotein A1 predict increased risk of developing World Trade Center-lung injury: a nested case-control study. Biomarkers. 2014;19(2):159-65.

66. Menezes AM, Perez-Padilla R, Wehrmeister FC, Lopez-Varela MV, Muino A, Valdivia $G$, et al. FEV1 is a better predictor of mortality than FVC: the PLATINO cohort study. PLOS ONE. 2014;9(10):e109732.

67. Puddu PE, Menotti A, Tolonen H, Nedeljkovic S, Kafatos AG. Determinants of 40-year all-cause mortality in the European cohorts of the Seven Countries Study. Eur J Epidemiol. 2011;26(8):595-608.

68. Hole DJ, Watt GC, Davey-Smith G, Hart CL, Gillis CR, Hawthorne VM. Impaired lung function and mortality risk in men and women: findings from the Renfrew and Paisley prospective population study. BMJ. 1996;313(7059):711-5 (discussion 5-6).

69. Jenkins C, Rodriguez-Roisin R. Quality of life, stage severity and COPD. Eur Respir J. 2009;33(5):953-5.

70. Tojo N, Ichioka M, Chida M, Miyazato I, Yoshizawa Y, Miyasaka N. Pulmonary exercise testing predicts prognosis in patients with chronic obstructive pulmonary disease. Intern Med. 2005;44(1):20-5.

71. Watz H, Waschki B, Meyer T, Magnussen H. Physical activity in patients with COPD. Eur Respir J. 2009;33(2):262-72.

72. Montes de Oca M, Talamo C, Perez-Padilla R, Jardim JR, Muino A, Lopez MV, et al. Chronic obstructive pulmonary disease and body mass index in five Latin America cities: the PLATINO study. Respir Med. 2008;102(5):642-50.

73. Osman IM, Godden DJ, Friend JA, Legge JS, Douglas JG. Quality of life and hospital re-admission in patients with chronic obstructive pulmonary disease. Thorax. 1997;52(1):67-71.

74. Adams KE, Rasmussen JC, Darne C, Tan IC, Aldrich MB, Marshall MV, et al. Direct evidence of lymphatic function improvement after advanced pneumatic compression device treatment of lymphedema. Biomed Opt Express. 2010;1(1):114-25.

75. Nolan A, Naveed B, Comfort AL, Ferrier N, Hall CB, Kwon S, et al. Inflammatory biomarkers predict airflow obstruction after exposure to World Trade Center Dust. Chest. 2011;142:412-8. 
76. Weiden MD, Naveed B, Kwon S, Cho SJ, Comfort AL, Prezant DJ, et al. Cardiovascular biomarkers predict susceptibility to lung injury in World Trade Center dust-exposed firefighters. Eur Respir J. 2013;41(5):1023-30.

77. Schenck EJ, Echevarria GC, Girvin FG, Kwon S, Comfort AL, Rom WN, et al. Enlarged pulmonary artery is predicted by vascular injury biomarkers and is associated with WTC-lung injury in exposed fire fighters: a case-control study. BMJ Open. 2014:4(9):e005575.

78. Uribarri J, Woodruff S, Goodman S, Cai W, Chen X, Pyzik R, et al. Advanced glycation end products in foods and a practical guide to their reduction in the diet. J Am Diet Assoc. 2010;110(6):911-16.e12.

79. Liu X, Yip J, Zeig-Owens R, Weakley J, Webber MP, Schwartz TM, et al. The effect of World Trade Center exposure on the timing of diagnoses of obstructive airway disease, chronic rhinosinusitis, and gastroesophageal reflux disease. Front Public Health. 2017:5:2.

80. Webber MP, Glaser MS, Weakley J, Soo J, Ye F, Zeig-Owens R, et al. Physician-diagnosed respiratory conditions and mental health symptoms 7-9 years following the World Trade Center disaster. Am J Ind Med. 2011;54(9):661-71.

81. Nolan A, Naveed B, Comfort AL, Ferrier N, Hall CB, Kwon S, et al. Inflammatory biomarkers predict airflow obstruction after exposure to world trade center dust. Chest. 2012;142(2):412-8.

82. Weiden MD, Naveed B, Kwon S, Segal LN, Cho SJ, Tsukiji J, et al. Comparison of WTC dust size on macrophage inflammatory cytokine release in vivo and in vitro. PLOS ONE. 2012;7(7):e40016.

83. Aldrich TK, Ye F, Hall CB, Webber MP, Cohen HW, Dinkels M, et al. Longitudinal pulmonary function in newly hired, non-World Trade Center-exposed fire department City of New York firefighters: the first 5 years. Chest. 2013;143(3):791-7.

84. Kwon S, Weiden MD, Echevarria GC, Comfort AL, Naveed B, Prezant DJ, et al. Early elevation of serum MMP-3 and MMP-12 predicts protection from World Trade Center-lung injury in New York City Firefighters: a nested case-control study. PLoS ONE. 2013;8(10):e76099.

85. Nolan A, Kwon S, Cho SJ, Naveed B, Comfort AL, Prezant DJ, et al. MMP-2 and TIMP-1 predict healing of WTC-lung injury in New York City firefighters. Respir Res. 2014;15:5.

86. Movassagh EZ, Baxter-Jones ADG, Kontulainen S, Whiting SJ, Vatanparast $\mathrm{H}$. Tracking dietary patterns over 20 years from childhood through adolescence into young adulthood: the saskatchewan pediatric bone mineral accrual study. Nutrients. 2017;9(9):990.

87. Mikkila $V_{\text {, }}$ Rasanen L, Raitakari OT, Marniemi J, Pietinen P, Ronnemaa T, et al. Major dietary patterns and cardiovascular risk factors from childhood to adulthood. The Cardiovascular Risk in Young Finns Study. Br J Nutr. 2007;98(1):218-25.

88. Newby PK, Weismayer C, Akesson A, Tucker KL, Wolk A. Long-term stability of food patterns identified by use of factor analysis among Swedish women. J Nutr. 2006;136(3):626-33.

89. Varraso R, Dumas O, Boggs KM, Willett WC, Speizer FE, Camargo CA $\mathrm{Jr}$. Processed meat intake and risk of chronic obstructive pulmonary disease among middle-aged women. EClinicalMedicine. 2019;14:88-95.

90. Salari-Moghaddam A, Milajerdi A, Larijani B, Esmaillzadeh A. Processed red meat intake and risk of COPD: a systematic review and dose-response meta-analysis of prospective cohort studies. Clin Nutr. 2019:38(3):1109-16.

91. Varraso R, Camargo CA Jr. The influence of processed meat consumption on chronic obstructive pulmonary disease. Expert Rev Respir Med. 2015;9(6):703-10.

92. Vlassara H, Uribarri J. Advanced glycation end products (AGE) and diabetes: cause, effect, or both? Curr Diab Rep. 2014;14(1):453.

93. Inan-Eroglu E, Ayaz A, Buyuktuncer Z. Formation of advanced glycation endproducts in foods during cooking process and underlying mechanisms: a comprehensive review of experimental studies. Nutr Res Rev. 2019;33:77-89.

94. Sharma C, Kaur A, Thind SS, Singh B, Raina S. Advanced glycation Endproducts (AGEs): an emerging concern for processed food industries. Food Sci Technol. 2015;52(12):7561-76.
95. Goldberg T, Cai W, Peppa M, Dardaine V, Baliga BS, Uribarri J, et al. Advanced glycoxidation end products in commonly consumed foods. J Am Diet Assoc. 2004;104(8):1287-91.

96. Park S, Blanck HM, Sherry B, Jones SE, Pan L. Regular-soda intake independent of weight status is associated with asthma among US high school students. J Acad Nutr Diet. 2013;113(1):106-11.

97. DeChristopher LR, Uribarri J, Tucker KL. Intakes of apple juice, fruit drinks and soda are associated with prevalent asthma in US children aged 2-9 years. Public Health Nutr. 2016:19(1):123-30.

98. Tabak C, Smit HA, Heederik D, Ocke MC, Kromhout D. Diet and chronic obstructive pulmonary disease: independent beneficial effects of fruits, whole grains, and alcohol (the MORGEN study). Clin Exp Allergy. 2001:31(5):747-55.

99. Walda IC, Tabak C, Smit HA, Rasanen L, Fidanza F, Menotti A, et al. Diet and 20-year chronic obstructive pulmonary disease mortality in middle-aged men from three European countries. Eur J Clin Nutr. 2002;56(7):638-43.

100. Kaluza J, Larsson SC, Orsini N, Linden A, Wolk A. Fruit and vegetable consumption and risk of COPD: a prospective cohort study of men. Thorax. 2017:72(6):500-9.

101. Meteran H, Thomsen SF, Miller MR, Hjelmborg J, Sigsgaard T, Backer $\checkmark$. Self-reported intake of fruit and vegetables and risk of chronic obstructive pulmonary disease: a nation-wide twin study. Respir Med. 2018;144:16-21.

102. Keranis E, Makris D, Rodopoulou P, Martinou H, Papamakarios G, Daniil Z, et al. Impact of dietary shift to higher-antioxidant foods in COPD: a randomised trial. Eur Respir J. 2010;36(4):774-80.

103. Baldrick FR, Elborn JS, Woodside JV, Treacy K, Bradley JM, Patterson CC, et al. Effect of fruit and vegetable intake on oxidative stress and inflammation in COPD: a randomised controlled trial. Eur Respir J. 2012;39(6):1377-84.

104. Holt EM, Steffen LM, Moran A, Basu S, Steinberger J, Ross JA, et al. Fruit and vegetable consumption and its relation to markers of inflammation and oxidative stress in adolescents. J Am Diet Assoc. 2009;109(3):414-21.

105. Cao C, Wang R, Wang J, Bunjhoo H, Xu Y, Xiong W. Body mass index and mortality in chronic obstructive pulmonary disease: a meta-analysis. PLoS ONE. 2012;7(8):e43892.

106. Sun Y, Milne S, Jaw JE, Yang CX, Xu F, Li X, et al. BMI is associated with FEV1 decline in chronic obstructive pulmonary disease: a meta-analysis of clinical trials. Respir Res. 2019;20(1):236.

107. Jitnarin N, Poston WS, Haddock CK, Jahnke SA, Day RS. Accuracy of body mass index-defined obesity status in US firefighters. Saf Health Work. 2014;5(3):161-4.

108. Grundy SM. AHA/ACC/AACVPR/AAPA/ABC/ACPM/ADA/AGS/APhA/ ASPC/NLA/PCNA Guideline on the Management of Blood Cholesterol: A Report of the American College of Cardiology/American Heart Association Task Force on Clinical Practice Guidelines (vol 139, pg e1082, 2019). Circulation. 2019;139(25):E1182-6.

109. Kim H, Baidwan NK, Kriebel D, Cifuentes M, Baron S. Asthma among World Trade Center First Responders: a qualitative synthesis and bias assessment. Int J Env Res Public Health. 2018;15(6):1053.

110. Mikkilae V, Rasnan L, Raitakari OT, Marniemi J, Pietinen P, Ronnemaa T, et al. Major dietary patterns and cardiovascular risk factors from childhood to adulthood. The Cardiovascular Risk in Young Finns Study. Br J Nutr. 2007;98(1):218-25.

111. Odencrants S, Ehnfors M, Grobe SJ. Living with chronic obstructive pulmonary disease: part I. Struggling with meal-related situations: experiences among persons with COPD. Scand J Caring Sci. 2005;19(3):230-9.

\section{Publisher's Note}

Springer Nature remains neutral with regard to jurisdictional claims in published maps and institutional affiliations. 